\title{
Lipopolysaccharide and its threatening zombie-like nature: unlive, harmful and tough (but not impossible) to eliminate
}

\author{
Gustavo Pompermaier Garlet
}

Co-Editor-in-Chief, Journal of Applied Oral Science

\section{Dear Readers,}

Within the multiple creatures that inhabit popular culture and science fiction, zombies have been the scientists' favorites in a series of scientific metaphors and representations ${ }^{11}$. Zombies are featured as dead entities with the appearance of life, presenting with a will-less behavior along an uncontained hunger. 'Walking dead' zombies hordes vague taken by a supernatural force for some evil purpose, spreading themselves with characteristic features of epidemic events and being extremely difficult to be contained; remember, they are already dead!

While the zombie-like behavior is frequently used as a metaphor by behavioral and psychological sciences ${ }^{7,18}$, recently such association has been used to describe some interesting discoveries of biological and health sciences. 'Zombie state' was recently used as a representation for a situation where cells are stabilized into apoptosis process, a well-known cell death process. These 'living dead' cells are described as intracellularly committed with apoptotic pathways and to present hallmark characteristics of genuine apoptotic cells, while their cellular cortex and plasma membrane remain intact or alive ${ }^{14}$. While this cellular zombie state does not naturally occur (it is induced by a drugs cocktail with diagnostic and therapeutic applications aims), the scientists responsible for its characterization promptly used the zombie analogy based on the cellular functional and structural state ${ }^{14}$. Still in cell biology field, 'the zombie hypothesis' was also used to describe 'degenerated but functional' centrioles (centrioles are conserved, self-replicating, microtubule-based subcellular organelles essential for cell division and function), which could account as a cause of infertility ${ }^{1}$.

Other appropriation of the zombie symbol refers to a remarkable host-parasite interaction setting ${ }^{20}$. Studies demonstrate that some parasites can manipulate host behavior allowing them to hijack host processes, to replicate and transmit to the next host. In other words, host lost their will into a zombie-like state, in a very complex process under the investigation of multiple fields including neurobiology, animal behavior, infectious disease and epidemiology ${ }^{6}$. A well-characterized example involves the generation of zombie ants, when Carpenter ants (genus Camponotus) are infected by the fungus Ophiocordyceps unilateralis sensu latu $(\text { s.l. })^{2}$. The zombie state includes a series of actions that are not part of the ant's normal behavior, such as leaving the nest at a different time of day, nondirected movements, convulsions, and climbing up the vegetation followed by a biting behavior followed by host-death, which assists the spore transmission post-mortem and perpetuates the zombie epidemy ${ }^{2}$. Similar situations are described with parasites that can manipulate the behavior of wasps, cockroaches and crustaceans ${ }^{19}$. It is interesting to remember that rabies (caused by rabies virus genotype 1 ), which commonly presents with classic furious rabies behavioral features (which include altered mental status, phobic or inspiratory spasms, and autonomic stimulation signs) ${ }^{10}$, is considered as one of the possible origins of the zombie legend.

Moving back to oral sciences field, specifically to the root canal system, we can apply the zombie analogy to an unlive, harmful and tough to eliminate threat, called lipopolysaccharide. The presence of live bacteria, specially Gram-negative species, have been associated with the pathogenesis of periapical lesions for decades, as well diverse actions targeted to kill such microorganisms have been applied during endodontic therapy ${ }^{13,17}$. However, it has been demonstrated that only killing the bacteria harboring the root canal system could not be enough to ensure a successful endodontic treatment outcome. The main reason is the existence of lipopolysaccharides (also called endotoxin, or simply LPS), a major component of outer layer of cell wall of Gramnegative bacteria, comprised of a hydrophilic polysaccharide and a hydrophobic component referred to as lipid A4. Over the years, multiple studies demonstrate that LPS was responsible, if not integrally at least in a great extent, for the harmful reactions of host to Gram-negative infecting agents. In addition, due its ability to elicit strong immune responses, the LPS becomes the prototypic activator of innate immune cells (and even stromal cells) in vitro and in vivo. Interestingly, the discovery of a LPS-resistance mice strains, such as the $\mathrm{C} 3 \mathrm{H} / \mathrm{HeJ}$, was a keystone in inflammation and immunology fields, supporting several essential studies in these areas many years before the contemporary discovery and characterization of LPS receptors, such as TLR44.

While in the majority of Gram-negative 
associated conditions, the killing of such bacteria by antimicrobials naturally results in the clearance of LPS from the host, despite the method (or multiple combined methods) of microbial killing performed along endodontic therapy, the unique nature of root canal system results in the reminiscence of dead bacterial cells in the intimacy of dentinal tubules. Therefore, despite efficient bacterial killing, the inefficacy of bactericidal therapies in the elimination of LPS from endodontic and periapical environment may affect the outcome of endodontic treatment in an unfavorable way. In fact, studies demonstrate the leakage of LPS from root canal after root filling with different materials ${ }^{12,19}$. Therefore, applying over the zombie analogy, killed and buried bacteria can give rise to 'walking dead' LPS, which similarly to their literature and movie theater counterparts, can be threatening and difficult to be contained. The hazard potential of remaining LPS in the root canal system was acknowledged by the endodontics field a long time $\mathrm{ago}^{5}$, and researches have put significant effort over the years to counteract the deleterious effects of LPS in the root canal system and periapex ${ }^{3,16}$. In this issue of the Journal of Applied Oral Science, Gründling, et al. ${ }^{8}$ add some important new information to the field, demonstrating the efficacy of a novel irrigant (composed by aqueous solution of EDTA, chlorhexidine and $\mathrm{N}$-cetyl$\mathrm{N}, \mathrm{N}$,Ntrimethylammonium bromide) in the reduction of LPS content and activity in root canal environment. Importantly, the data presented herein reinforces that usual irrigants used in endodontic practice, namely $\mathrm{NaOCl}$, clorhexidine and EDTA, have not been able to reduce the LPS load inside the root canal system.

If LPS and its zombie-like nature is still threatening, the continuous translational research efforts, such as the study presented here by Gründling et al. ${ }^{8}$, are providing us the tools to deal with it in the clinical reality, and the current fear from the 'walking-dead' will soon probably find its end.

\section{REFERENCES}

1- Avidor-Reiss T, Khire A, Fishman EL, Jo KH. Atypical centrioles during sexual reproduction. Front Cell Dev Biol. 2015;3:21.

2- Bekker C de, Ohm RA, Loreto RG, Sebastian A, Albert I, Merrow $M$, et al. Gene expression during zombie ant biting behavior reflects the complexity underlying fungal parasitic behavioral manipulation. BMC Genomics. 2015;16(1):620.

3- Buck RA, Cai J, Eleazer PD, Staat RH, Hurst HE. Detoxification of endotoxin by endodontic irrigants and calcium hydroxide. J Endod. 2001;27(5):325-7.

4- Calabrese V, Cighetti R, Peri F. Molecular simplification of lipid A structure: TLR4-modulating cationic and anionic amphiphiles. Mol Immunol. 2015;63(2):153-61

5- Dahlén G, Hofstad T. Endotoxic activities of lipopolysaccharides of microorganisms isolated from an infected root canal in Macaca cynomolgus. Scand J Dent Res. 1977;85(4):272-8.

6- Esteban DJ, Holloway KS. Mad dogs, vampires, and zombie ants: a multidisciplinary approach to teaching neuroscience, behavior, and microbiology. J Undergrad Neurosci Educ. 2015;13(2):A81-7. 7- Guitton MJ, Cristofari C. Does surviving the zombie apocalypse represent a good model of human behavior in response to pandemics? J Public Health Manag Pract. 2014;20(4):375-7.

8- Gründling GL, Melo TAF de, Montagner F, Scarparo RK,VierPelisser FV. QMix ${ }^{\circledR}$ irrigant reduces lipopolysaccharide (LPS) levels in an in vitro model. J Appl Oral Sci, 2015;23(4):430-40.

9- Harding R, Peel E. 'He was like a zombie': off-label prescription of antipsychotic drugs in dementia. Med Law Rev. 2013;21(2):24377.

10- Hemachudha T, Ugolini G, Wacharapluesadee S, Sungkarat W, Shuangshoti S, Laothamatas J. Human rabies: neuropathogenesis, diagnosis, and management. Lancet Neurol. 2013;12(5):498-513. 11- Koch C, Crick F. The zombie within. Nature. 2001;411(6840):893. 12- Laghios CD, Cutler CW, Gutmann JL. In vitro evidence that lipopolysaccharide of an oral pathogen leaks from root-end filled teeth. Int Endod J. 2000;33(4):333-9.

13- Morse DR, Furst ML, Belott RM, Lefkowitz RD, Spritzer IB, Sideman $\mathrm{BH}$. Infectious flare-ups and serious sequelae following endodontic treatment: a prospective randomized trial on efficacy of antibiotic prophylaxis in cases of asymptomatic pulpal-periapical lesions. Oral Surg Oral Med Oral Pathol. 1987;64(1):96-109.

14- Oropesa-Ávila M, Andrade-Talavera Y, Garrido-Maraver J, Cordero MD, de la Mata M, Cotán D, et al. Stabilization of apoptotic cells: generation of zombie cells. Cell Death Dis. 2014;5:e1369. 15- Qureshi ST, Gros P, Malo D. The Lps locus: genetic regulation of host responses to bacterial lipopolysaccharide. Inflamm Res. 1999;48(12):613-20.

16- Safavi KE, Nichols FC. Effect of calcium hydroxide on bacterial lipopolysaccharide. J Endod. 1993;19(2):76-8.

17- Sundqvist G, Reuterving CO. Isolation of Actinomyces israelii from periapical lesion. J Endod. 1980;6(6):602-6.

18- Tandy C. Are you (almost) a zombie?: conscious thoughts about "consciousness in the universe" by Hameroff and Penrose. Phys Life Rev. 2014;11(1):89-90; discussion 94-100.

19- Tang HM, Torabinejad M, Kettering JD. Leakage evaluation of root end filling materials using endotoxin. J Endod. 2002;28(1):57.

20- Weinersmith K, Faulkes Z. Parasitic manipulation of hosts' phenotype, or how to make a zombie--an introduction to the symposium. Integr Comp Biol. 2014;54(2):93-100. 